\title{
PENGARUH FASE MENSTRUASI TERHADAP DERAJAT AKNE VULGARIS MAHASISWI FAKULTAS KEDOKTERAN UNIVERSITAS RIAU
}

\author{
Alida Widiawaty, Endang H. Darmani, Amelinda \\ Fakultas Kedokteran Universitas Riau
}

\begin{abstract}
ABSTRAK
Akne vulgaris merupakan penyakit inflamasi kronik unit pilosebasea yang ditandai adanya komedo, papul, pustul, nodul dengan tempat predileksi di wajah, lengan bagian atas, dada, dan punggung, yang sering terjadi pada remaja serta dewasa muda. Akne vulgaris pada wanita dapat dipengaruhi oleh hormon yaitu pada saat premenstruasi terjadi penurunan hormon estrogen dan peningkatan hormon progesteron yang dapat memperberat akne vulgaris.

Tujuan penelitian ini adalah untuk mengetahui hubungan fase menstruasi dengan derajat akne vulgaris. Dilakukan penelitian analitik observasional pada 89 mahasiswa yang menderita akne vulgaris. Penilaian derajat akne vulgaris menggunakan kriteria Lehmann saat premenstruasi dan pascamenstruasi. Subjek penelitian terdiri atas remaja usia 17 sampai 21 tahun. Uji Marginal Homogeneity menunjukkan hubungan yang bermakna antara fase menstruasi dengan derajat akne vulgaris dengan nilai $p=0,001$.
\end{abstract}

Kata Kunci: Akne vulgaris, fase menstruasi, derajat akne vulgaris.

\section{THE EFFECT OF MENSTRUAL PHASE WITH ACNE VULGARIS GRADE OF THE MEDICAL STUDENTS UNIVERSITAS RIAU}

\author{
ABSTRACT \\ Acne vulgaris is an inflammatory disease in the pilosebaceus unit characterized by \\ comedones, papules, pustules, or nodules that usually affecting adolescents as well as young adults. Its \\ predilection are face, upper shoulders, chest, and back. Acne vulgaris that is affected by hormones at the time \\ of premenstruation which estrogen hormone is decreasing and progesterone level is increasing that can \\ aggravate acne vulgaris. \\ The aim of this study is to determine whether there is a relationship between menstrual phase with acne \\ vulgaris' severity grade. An observational analytic study was performed on 89 students age 17 to 21 years \\ suffering from acne vulgaris. The degree of acne vulgaris assessed using Lehmann's criteria before and after \\ menstrual period. Marginal Homogeneity test showed a significant relationship between menstrual phase and \\ degree of acne vulgaris $(p=0,001)$.
}

Keywords: Acne vulgaris, menstrual phase, grade of acne vulgaris

Korespondensi:

Jl. Diponegoro No. 1 Pekanbaru,

Riau 28133

Telp/Fax: +62 (0761) 839264

839265, Fax: +62 (0761) 839265

Email:widiawatyalida@gmail.com 


\section{PENDAHULUAN}

Akne vulgaris (AV) adalah penyakit inflamasi pada unit pilosebasea ditandai lesi inflamasi dan lesi non inflamasi di daerah predileksi yang sering terjadi pada remaja serta dewasa muda. ${ }^{1}$ Data prevalensi AV di Surabaya terjadi peningkatan dari tahun 2010 sebesar $27,79 \%$ menjadi $51,60 \%$ pada tahun $2012 .^{2}$ Data dari Rumah Sakit Umum Daerah (RSUD) Arifin Achmad Pekanbaru dari tahun 2016 sampai tahun 2017 terjadi peningkatan persentase insiden AV di usia 15-24 tahun dari $65 \%$ menjadi $71,7 \%$. Puncak insiden kasus AV pada usia 15-24 tahun, dengan persentase kasus AV lebih tinggi pada perempuan $(38,7 \%)$ dibanding laki-laki $(27,6 \%){ }^{2}$ Data dari Rumah Sakit Umum (RSU) Malang didapatkan karakteristik AV berdasarkan tingkatan pendidikan, yaitu banyak pada tingkat diploma/ perguruan tinggi dengan persentase $42,10 \%$ pada tahun 2016 . $^{3}$

Akne vulgaris dipengaruhi berbagai faktor antara lain hormon, genetik, kosmetik, makanan, kondisi kulit, pekerjaan dan stres psikis. ${ }^{4}$ Akne vulgaris pada wanita berkembang lebih awal yaitu pada awal premenarke. ${ }^{5}$ Pada masa remaja terjadi peningkatan hormon seks terutama hormon androgen yang menyebabkan terjadinya peningkatan ukuran kelenjar sebasea, menstimulasi produksi sebum, dan proliferasi keratinosit pada duktus kelenjar sebasea dan akroinfundibulum sehingga terbentuknya lesi noninflamasi dan lesi inflamasi. ${ }^{5,6}$

Penelitian oleh Ayudianti di RSUD Dr. Soetomo Surabaya tahun 2014 menunjukkan hormon sebagai fakfor pencetus tersering AV dengan persentase berdasarkan jenis kelamin yang dipengaruhi oleh hormon, yaitu $89,0 \%$ pada perempuan dan $11,0 \%$ pada laki-laki. Hormon lebih berpengaruh pada wanita saat menstruasi dan peningkatan hormon sebelum menstruasi akan memengaruhi eksaserbasi serta memperburuk $\mathrm{AV}{ }^{7}$

Penelitian oleh Raghunanth menunjukkan bahwa kondisi premenstruasi meningkatkan angka kejadian AV dibanding pascamenstruasi. ${ }^{8}$ Penelitian oleh Siregar EDU pada tahun 2016 terhadap santriwati Sekolah Menengah Atas (SMA) Islam Terpadu Surakarta, didapatkan 41 dari 55 orang santriwati $(74,50 \%)$ yang mengalami peningkatan gradasi AV dari ringan ke berat pada saat menstruasi. ${ }^{9}$

Siklus menstruasi memiliki beberapa hormon yang turut berperan di antaranya Follicle Stimulating Hormone (FSH) dan Luteinizing Hormone (LH) yang akan berpengaruh pada regulasi hormon androgen, progesteron, dan estrogen. Hormon merupakan faktor endogen penyebab terjadinya AV dan ikut berpartisipasi pada derajat $\mathrm{AV} .{ }^{10}$ Derajat $\mathrm{AV}$ ringan, sedang dan berat ditentukan berdasarkan jumlah lesi, yaitu lesi noninflamasi dan lesi inflamasi. Lesi noninflamasi berupa komedo dan lesi inflamasi berupa papul, pustul, nodul. ${ }^{11}$

\section{METODE PENELITIAN}

\section{Subjek}

Subjek penelitian (SP) adalah mahasiswi Fakultas Kedokteran Universitas Riau (FK UNRI) yang menderita AV.

\section{Metode}

Penelitian ini adalah analitik observasional pada mahasiswi FK UNRI yang dilakukan pada bulan Oktober 2017 sampai April 2018. Besar sampel ditentukan berdasarkan rumus Lameshow/Slovin. ${ }^{12}$ Kriteria inklusi pada penelitian ini adalah mahasiswi yang menderita $\mathrm{AV}$, tidak sedang dalam pengobatan AV saat dilakukan penelitian, siklus menstruasi teratur, tidak didiagnosis hirsutisme dan Polycystic Ovary Syndrome (PCOS), tidak sedang mengonsumsi obat-obatan yang dapat memicu AV misalnya isoniazid (INH), kortikosteroid, serta tidak menggunakan kosmetik yang bersifat komedogenik.

Derajat AV dinilai menurut kriteria Lehmann dan dilakukan penilaian derajat $\mathrm{AV}$ pada saat premenstruasi dan pascamenstruasi. Subjek penelitian dianamnesis dan dilakukan dua kali penilaian derajat AV yaitu pada saat premenstruasi dan pascamestruasi. Penilaian derajat AV dengan menghitung jumlah lesi inflamasi, kemudian jumlah lesi tersebut dapat menentukan derajat AV. Adanya perubahan derajat AV pada saat premenstruasi dan pascamenstruasi dapat membuktikan adanya hubungan fase menstruasi dengan derajat AV.

\section{Analisis statistik}

Analisis statistik dilakukan menggunakan uji Marginal Homogeneity dengan bantuan program komputer, dinyatakan hubungan yang bermakna apabila nilai $\mathrm{p}<0,05$.

\section{HASIL PENELITIAN}

\section{Karakteristik subjek penelitian}

Karakteristik SP yang dinilai adalah usia, lama menderita $\mathrm{AV}$, usia awal timbul $\mathrm{AV}$, riwayat keluarga menderita $\mathrm{AV}$, dan siklus menstruasi seperti yang tercantum pada tabel 1 .

Karakteristik usia SP terbanyak adalah 18 tahun yang berjumlah $36(40,4 \%)$. Lama menderita AV terbanyak adalah selama 2 tahun pada 23 SP $(25,8 \%)$. Usia awal timbul AV terbanyak di usia 15 tahun yang berjumlah 26 SP $(29,2 \%)$. Subjek penelitian yang memiliki riwayat keluarga yang menderita $\mathrm{AV}$ ada 61 orang dan sebanyak $27 \mathrm{SP}(30,3 \%)$ yang memiliki riwayat keluarga AV dari ibu. Panjang siklus menstruasi SP terbanyak adalah selama 28 hari (39,3\%). 
Tabel 1. Karakteristik subjek penelitian berdasarkan usia, lama menderita $A V$, usia awal timbul $A V$, riwayat keluarga menderita AV, siklus mestruasi

\begin{tabular}{|c|c|c|}
\hline Karakteristik subjek & Frekuensi (N) & Persentase (\%) \\
\hline \multicolumn{3}{|l|}{ Usia subjek } \\
\hline 17 tahun & 9 & 10,1 \\
\hline 18 tahun & 36 & 40,4 \\
\hline 19 tahun & 28 & 32,6 \\
\hline 20 tahun & 14 & 14,6 \\
\hline 21 tahun & 3 & 3,4 \\
\hline \multicolumn{3}{|l|}{ Lama menderita AV } \\
\hline 1 tahun & 10 & 11,2 \\
\hline 2 tahun & 23 & 25,8 \\
\hline 3 tahun & 20 & 22,5 \\
\hline 4 tahun & 16 & 18 \\
\hline 5 tahun & 20 & 22,5 \\
\hline \multicolumn{3}{|l|}{ Usia awal timbul AV } \\
\hline 13 tahun & 8 & 9 \\
\hline 14 tahun & 13 & 14,6 \\
\hline 15 tahun & 26 & 29,2 \\
\hline 16 tahun & 23 & 25,8 \\
\hline 17 tahun & 13 & 14,6 \\
\hline 18 tahun & 6 & 6,7 \\
\hline \multicolumn{3}{|l|}{$\begin{array}{l}\text { Riwayat keluarga } \\
\text { menderita } \mathrm{AV}\end{array}$} \\
\hline \multicolumn{3}{|l|}{ Ada riwayat keluarga } \\
\hline Ayah & 21 & 23,6 \\
\hline Ibu & 27 & 30,3 \\
\hline Ayah dan Ibu & 13 & 14,6 \\
\hline Tidak ada riwayat keluarga & 28 & 31,5 \\
\hline \multicolumn{3}{|l|}{ Siklus menstruasi } \\
\hline 21 hari & 5 & 5,6 \\
\hline 24 hari & 1 & 1,1 \\
\hline 25 hari & 2 & 2,2 \\
\hline 26 hari & 4 & 4,5 \\
\hline 27 hari & 3 & 3,4 \\
\hline 28 hari & 35 & 39,3 \\
\hline 29 hari & 2 & 2,2 \\
\hline 30 hari & 4 & 4,5 \\
\hline 31 hari & 12 & 13,5 \\
\hline 32 hari & 4 & 4,5 \\
\hline 33 hari & 2 & 2,2 \\
\hline 34 hari & 1 & 1,1 \\
\hline 35 hari & 14 & 15,7 \\
\hline
\end{tabular}

\section{Hubungan fase menstruasi dengan derajat akne vulgaris}

Subjek penelitian yang mengalami perubahan derajat AV dari ringan saat premenstruasi menjadi sedang saat pascamenstruasi sebanyak 1 orang. Penurunan derajat AV dari sedang saat premenstruasi menjadi ringan pasca menstruasi dialami oleh 10 SP. Sedangkan dari derajat berat ke sedang terjadi pada 3 SP. Derajat AV yang menetap saat premenstruasi maupun pascamenstruasi terdapat pada $75 \mathrm{SP}$, yaitu $70 \mathrm{SP}$ tetap derajat ringan dan 5 SP tetap derajat sedang.

Hasil uji Marginal Homogeneity didapatkan hubungan yang bermakna antara fase menstruasi dengan derajat AV dengan nilai $\mathrm{p}=0,001$.
Tabel 2. Hasil uji Marginal Homogeneity

\begin{tabular}{llccccc}
\hline & & \multicolumn{9}{c}{ AV pascamenstruasi } & \multirow{2}{*}{ Total } & \multirow{2}{*}{ Pingan } \\
& & Sedang & Berat & To & \\
\hline AV & Ringan & 70 & 1 & 0 & 71 & 0,001 \\
premenstruasi & & & & & & \\
& Sedang & 10 & 5 & 0 & 15 & \\
\multirow{5}{*}{ Total } & Berat & 0 & 3 & 0 & 3 & \\
\hline
\end{tabular}

Untuk melihat adanya perbedaan rerata lesi AV premenstruasi dan pascamenstruasi dengan distribusi data yang normal dilakukan uji t berpasangan seperti yang tercantum pada tabel 3. Uji normalitas data menggunakan uji Kolmogorov-Smirnov karena data berjumlah $>50$. Hasil uji $t$ berpasangan AV premenstruasi dan pascamenstruasi terdapat perbedaan rerata $(4,789 \pm 9,273)$ dengan interval kepercayaan (IK) 95\% dan nilai $\mathrm{p}=0,0000$, sehingga dapat disimpulkan adanya perbedaan rerata lesi AV premenstruasi dan pascamentruasi.

Tabel 3. Hasil uji t berpasangan

\begin{tabular}{lccccc}
\hline & N & Rerata \pm s.b. & $\begin{array}{l}\text { Perbedaan } \\
\text { Rerata } \pm \text { s.b. }\end{array}$ & IK 95\% & p \\
\hline $\begin{array}{l}\text { Inflamasi } \\
\text { premens- } \\
\text { truasi }\end{array}$ & 89 & $10,72 \pm 14,443$ & $4,789 \pm 9,273$ & $6,751 \pm 2,844$ & $<0,000$ \\
$\begin{array}{l}\text { Inflamasi } \\
\text { pascamens- } \\
\text { truasi }\end{array}$ & 89 & $5,92 \pm 8,266$ & & & \\
\hline $\begin{array}{l}\text { Keterangan: s.b.= simpang baku } \\
\end{array}$ & & & & \\
\end{tabular}

\section{PEMBAHASAN}

Hubungan Fase menstruasi dengan derajat akne vulgaris

Akne vulgaris pada masa remaja biasanya dimulai saat masa pubertas, karena tubuh memproduksi hormon pertumbuhan lebih tinggi, sehingga akan merangsang testosteron, adrenal, dan ovarium untuk menghasilkan hormon androgen poten seperti dihydrotestosterone (DHT) lebih banyak dan akan menyebabkan peningkatan ukuran kelenjar sebasea, peningkatan produksi sebum sehingga terbentuk AV. ${ }^{10,13-15}$ Berdasarkan hasil analisis statistik didapatkan hubungan yang bermakna antara fase menstruasi dengan derajat $\mathrm{AV}$ dan terdapat perbedaan rerata lesi inflamasi premenstruasi dengan pascamenstruasi. Hasil ini sesuai dengan penelitian oleh Astuti DW yang menyatakan ada hubungan antara menstruasi dengan angka kejadian AV pada remaja yang paling banyak ditemukan sebelum menstruasi $(41,7 \%) .{ }^{16}$ Penelitian lain yang dilakukan oleh Aprillia E juga menyatakan terdapat hubungan antara menstruasi dengan eksaserbasi AV. ${ }^{17}$ Penelitian oleh Kundre RM menyatakan terdapat hubungan yang bermakna antara keteraturan siklus menstruasi dengan kejadian AV. ${ }^{18}$ 
Saat premenstruasi atau fase luteal pada siklus menstruasi terjadi peningkatan hormon androgen dan progesteron yang merupakan salah satu faktor endogen terjadinya AV. Sebum disintesis oleh kelenjar sebasea secara terus-menerus dan disekresikan ke permukaan kulit melalui pori-pori folikel rambut. Kelenjar sebasea menjadi aktif ketika terjadinya peningkatan hormon androgen. Hormon tersebut akan menyebabkan peningkatan ukuran kelenjar sebasea, menstimulasi produksi sebum, serta menstimulasi proliferasi keratosit pada duktus kelenjar sebasea dan akroinfundibulum. Proses keratinisasi pada folikel rambut akan menyebabkan penyumbatan saluran sekresi sebum. $^{15,19}$

Penyumbatan keratin di saluran pilosebasea karena proses keratinisasi yang dirangsang oleh hormon androgen, sebum, asam lemak bebas, dan skualen. Penyumbatan yang terjadi menyebabkan terbentuknya kolonisasi mikroorganisme di dalam folikel sebasea yang menimbulkan inflamasi, sehingga folikel berisi lipid dan komponen keratin yang masuk kedalam dermis. ${ }^{15,19}$

Pascamenstruasi atau fase folikuler siklus menstruasi hormon estrogen yang tinggi berpengaruh pada pembentukan AV. Hormon estrogen memiliki peran penting dalam memengaruhi produksi sebum dengan menghambat produksi hormon androgen. Peningkatan hormon estrogen pada fase folikuler menyebabkan penurunan ukuran dan pertumbuhan kelenjar serta menurunkan produksi sebum yang menyebabkan penurunan jumlah lesi AV. Penurunan kadar hormon estrogen fase luteal atau premenstruasi menyebabkan tidak adanya penghambatan produksi hormon androgen, sehingga dapat mengakibatkan terjadinya peningkatan jumlah $\mathrm{AV} .{ }^{13,14}$

Penelitian ini juga didukung oleh penelitian Astuti (2011) yang menyatakan ada hubungan antara menstruasi dengan angka kejadian AV pada remaja yang paling banyak ditemukan sebelum menstruasi $(41,7 \%) .{ }^{16}$ Penelitian ini juga didukung oleh penelitian Aprillia (2010) yang menyatakan terdapat hubungan antara menstruasi dengan eksaserbasi AV. ${ }^{17}$ Sementara itu penelitian oleh Kundre (2016) menyatakan bahwa terdapat hubungan yang bermakna antara keteraturan siklus menstruasi dengan kejadian $\mathrm{AV}{ }^{18}$

\section{SIMPULAN}

Terdapat hubungan yang bermakna antara fase menstruasi dengan derajat AV dengan nilai $\mathrm{p}<0,05$, dan terdapat perbedaan rerata lesi inflamasi premenstruasi dan pascamenstruasi.

\section{DAFTAR PUSTAKA}

1. Zaenglein AL, Graber EM, Thiboutot DM, Strauss JS. Acne vulgaris. Dalam: Fitzpatrick TB, Eisen AZ, Wolff K, Freedberg IM, Austen K. Dermatology in general medicine. Edisi ke-6. New York: McGraw-Hill, 2012.h.77-82.
2. Rimadhani M, Rahmadewi. Oral antibioticvin acne vulgaris patients: restrospective study. BIKKK. 2015;27(2):84-9.

3. Kumala YD, Rifiq A, Murlistyarini S. Kadar interleukin12 serum pada berbagai derajat keparahan akne vulgaris di RSU Dr. Saiful Anwar Malang. JKM. 2016;1(3):120-9.

4. Moneam AA, Eddin W MHD N, Taqi AMGM, Lafta AR, Shamssain M, Shahwan M, dkk. The Prevalence and Factor Affecting Acne Vulgaris Among University Students. EJPMR 2016; 3 (6):101-7.

5. James WD. Clinical practice Acne. N Eng J Med 2005; 352 (14): 1463-72.

6. Inoue T, Miki Y, Kakuo S, Hachiya A, Kitahara T, Alba $\mathrm{S}$, et al. Expression of Steroidogenic Enzymes in Human Sebaceous Glands. J Endocrinol. 2014; 222, 301-12.

7. Ayudianti P, Indramaya DM. Retrospective: factors aggravating acne vulgaris. BIKKK. 2014;26(1):41-7.

8. Raghunanth RS, Venables ZC, Millington GWM. The menstrual cycle and the skin. CED. 2015;40(2):111-5.

9. Siregar EDU. The correlation between menstrual cycle disorder with existence acne vulgaris on student of integrated islamic high school of nur hidayah kartasura. Biomedika.2017;8(2):20-4.

10. Samsulhadi. Haid dan Siklusnya. Dalam: Prawirohardjo S. Ilmu kandungan edisi 3. Jakarta: PT Bina Pustaka Sarwono Prawirohardjo. 2011. h.73-91.

11. Lehmann HP, Robinson KA, Andrews JS, Holloway V, Goodman SN. Acne therapy: a methodologic review. J Am Acad Dermatol. 2003;47:231-40.

12. Dahlan MS. Besar sampel dan cara pengambilan sampel dalam penelitian kedokteran dan kesehatan edisi 3 . Jakarta: Salemba Medika.2013. h.19-24.

13. Elsaie ML. Clinical, cosmetic and investigational dermatology: Hormonal treatment of acne vulgaris: an update. PMC. 2016:9:241-8.

14. Bakry OA, Shazly RMAE, Farargy SME, Kotb D. Role of hormones and blood lipids in the pathogenesis of acne vulgaris in non-obese, non-hirsute famales. Indian Dermatol Online J. 2014: 5(1):9-16.

15. Webster GF. Overview of the Pathogenesis of Acne. in: Webster GF, Raulings AV. Acne and itsTherapy series 40. New York: SUNY Donwstate Medical Center, 2007.h.1-8

16. Astuti DW. Hubungan antara menstruasi dengan angka kejadian akne vulgaris pada remaja [Tesis]. Semarang: Fakultas Kedokteran Universitas Diponegoro; 2011.

17. Aprillia E. Hubungan antara menstruasi dengan eksaserbasi akne vulgarisp pada santriwati pondok pesantren modern islam assalam surakarta [Tesis]. Surakarta: Fakultas Kedokteran Universitas Muhammadiyah Surakarta; 2010.

18. Kundre RM. Hubungan keteraturan siklus menstruasi dengan kejadian akne vulgaris pada mahasiswa semester II di program studi ilmu keperawatan Fakultas Kedokteran Universitas Sam Ratulangi Manado. 2016;4(2).

19. Sitohang IBS, Wasitatmaja SM. Akne Vulgaris. Dalam: Menaldi SLWS, Bramono K, Indriani W. Ilmu penyakit kulit dan kelamin edisi ke tujuh. Jakarta: Balai Penerbit Fakultas Kedokteran Universitas Indonesia, 2015. h. 288-92 